are all strongly biased towards this functional aspect. The opening address of the president, Prof. Richard Goldschmidt, on what he called the dynamic versus the static approach in genetics, put into a nutshell what became increasingly clear as the work of the Congress proceeded.

Another impression from the papers presented at the Congress is that the microscopic study of the chromosomes has reached an impasse, except as a branch of comparative morphology : it is waiting for substantially new techniques and substantially new ideas. As for the former, there was one demonstration on electron microscopy of chromosomes in meiosis which was of enough interest to suggest that this might be one of the new techniques.

The genus Drosophila has now come back into its own for a new purpose: the study of natural populations. Under the stimulus of genetic investigation so much work has been done on the systematics, the ecology, the comparative anatomy (including comparative karyology) of the innumerable species of Drosophila that this genus is now the ideal tool in this field.

The numerous papers presented showed that the interest in quantitative inheritance has expanded enormously since the last Congress. If its exponents can keep the distinction between statistical tools and biological ends clear, this is obviously a field of great future importance.

As to human genetics, there is a growing interest both in the study of inheritance of particular conditions and of the comparative genetics of populations. Indeed, man talies now a rank not far from that of Drosophila and of micro-organisms as a subject for genetic research.

The Congress will certainly give fruits both in the direction of personal friendship, renewed or promoted de novo, and of new ideas arising from cross-fertilization.

G. Pontecorvo

\section{INDUSTRIAL RESEARCH DIRECTORS}

T THE report of the third Conference of Industrial Research Directors and Research Managers, organized by the Industrial Research Committee of the Federation of British Industries, which was held at Ashorne Hill during April 17-19, 1953, has now been published*. The main subject of the conference was the commercial utilization of research results, and the report thus deals with an aspect of productivity with which the Advisory Council on Scientific Policy and the Department of Scientific and Industrial Research are increasingly concerned. Dealing with the problem from the point of view of company management, Lord Baillieu, who outlined policy and practice in the Dunlop Rubber Co., urged that it is essential to operate within our resources of finance, man-power and equipment. Research programmes should be conceived and keenly reviewed in terms of the conditions which a new idea or discovery must meet to achieve success; but we should not lose sight of the wider horizons and fundamental researches which have challenged the ingenuity and courage of men, and to which the British genius has responded so outstandingly. From the production

* Federation of British Industries. Report of the Third Conference of Industrial Directors and Managers, Ashorne Hill, 1953. Pp. vi+ point of view, Mr. G. S. Samways thought that in the metal container industry science has opened the way to revolutionary rather than evolutionary changes; research presents a problem not in finding ideas or in the method of implementation, but in finding the right type of young men and the large capital investment required. From the research point of view, Dr. N. P. Inglis urged the importance of a full and harmonious relationship between research and production departments. Elimination of problems of understanding, communications, joint consultation, etc., is largely a matter of personnel, and particularly of securing the right personnel and moving them about in the right way in their early years. Mr. E. R. Davies, describing the relations between research work and production in Kodak, Ltd., emphasized the way in which collaboration between plant and research workers is fostered by frequent informal as well as formal contacts, though the manufacturing departments are not paralleled entirely by laboratory groups in the research department; the four main types of manufacturing activity have been kept successfully in touch with development work and research groups through a system of four senior co-ordinators. Mr. J. B. Mitford stated that in Fibreglass, Ltd., the production department looks to the research department for new manufacturing methods, or revolutionary improvements in existing methods, for the rapid tracing and elimination of eauses of trouble in regular manufacture, and for the provision of a testing and advisory service on raw materials and finished products. Frequently, he admitted, the production side is at fault in failing to give the whole of the facts, and he stressed the necessity of research and development men establishing a high reputation with the junior management and production people at the foremen-level.

The papers on utilization of research results as a sales problem, whether from the sales or the research point of view, and the subsequent discussion indicated that it is not quite so easy to establish a satisfactory relation between research and sales departments as between research and production departments. The essential point seems to be to maintain a proper balance and relation in the traffic of ideas between the two departments, and it is desirable that the practical experience of the sales side should receive full consideration in any dis. cussions on the shaping of research and the evaluation of research progress. There is a place for creativeminded scientists with commercial instincts in the sales organization, in order to digest the import of sales intelligence and translate it into research ideas; but Dr. H. E. Merritt pointed out that it is also essential that the product situation should be reviewed, past performance appraised and probable future trends analysed at a high level in management. Much discussion centred on the training of salesmen, though the need for technical training was also fully recognized.

The fourth session was concerned with creating the right atmosphere. This, Mr. H. C. H. Graves urged, is partly a matter of human relations, and he thought there is room for some research into administrative methods, etc., of improving co-operation. If the importance, integrity and dignity of the individual are recognized, group attitudes would adjust themselves satisfactorily: the important thing is to encourage the right overall attitude to the economic objectives of the firm and industry, and appreciation 
of the individual as a participant in a team working for a common end. Mr. H. W. G. Hignett maintained that the preservation of good relations between the research department and other departments depends mainly on mutual respect, which can be engendered in many ways, not all of them technical. From a purely technical point of view, Mr. Hignett urged that four maxims should be observed: never give advice until all relevant facts are known and the background is clearly understood ; with this proviso, never fear to criticize when constructive criticism is in the company's interest; never relax efforts to make research reports concise and clear; and, wherever possible, let other departments take more than their fair share of the credit for exploiting the results of research. Finally, to secure full value from the research effort of Great Britain, we need a little more imagination and a lot more courage. Discussion centred on the importance of good organization, the danger of over-organization destroying personal initiative, and the need for making all workers aware of the dependence of our economic survival upon the development and exploitation of new research ideas. The right atmosphere can be created on the basis of mutual trust in one another and in each other's integrity and sincerity of purpose.

\section{ATHLONE FELLOWSHIP SCHEME FOR CANADIAN ENGINEERS}

$\mathrm{T}$ HE Athlone Fellowship Scheme, now in its third year of operation, is designed to bring to Great Britain every year thirty-eight Canadian graduates in engineering for postgraduate studies extending over two years. The Fellowships are tenable in industry or in a university, or may be divided between both. They cover the cost of travel to and from the United Kingdom, with a subsistence allowance of $\mathfrak{E} 610 \mathrm{~s}$. a week, the cost of tuition at a university and allowance towards text-books, and a travel grant of $£ 25$ a year for journeys within the United Kingdom. The net cost of the scheme is carried by the British Government. Some account of the operation of the Scheme was given by Dr. W. Abbott in a paper read by him on April 10 at a joint meeting of the Institutions of Civil Engineers, Mechanical Engineers and Electrical Engineers.

There are two classes of award: one for those about to graduate, on a quota basis, which ensures not fewer than two awards in each Canadian university (with the exception of New Brunswick); and, on a national basis, for those who have already graduated and are at work. The latter selection is at present experimental. The fundamental aim of the Scheme is to familiarize Canadian graduates with British industry, and it is thus desirable to ensure that as many as possible of the Fellows enter industry and saturate themselves with workshop techniques and the products thereof. Most graduates, however, have preferred to continue their studies in a university, with the view of securing a higher degree. This is due to the fact that North America is 'higher-degree conscious' to a much greater extent than is Great Britain, and research appointments in Canada invariably call for higher degrees, usually the doctorate. During 1952-53 eighteen of the Fellows opted for university training, and only nine for industrial training, as compared with twelve each, respectively, during 1951-52, and if this trend continues the basis of the Scheme may require re-examination.

The Scheme is best suited to the requirements of the graduates in mechanical, electrical and chemical engineering, the position in civil engineering being more difficult because much of the work of prime interest to Canadian engineers-for example, water conservation and irrigation schemes-lies overseas. Perhaps the most important single factor operating against the success of the Scheme is the intense demand for graduates from all branches of the engineering industry, both in Canada and the United States. Higher starting salaries, as much as 400 dollars a month, are offered, with attractive conditions. Only graduates able to take the long view are likely to offer themselves for Fellowships, and it is probable that the great bulk of the graduates with a practical bent do not apply for Fellowships but seize the opportunities now presented in Canada. So far as each individual is concerned, the success of the Scheme depends very largely on the people he meets during his training, and upon the people with whom he lives. Not all of these may be much concerned to send the young man home with a good opinion of Britain and its institutions.

\section{CONTROL OF MULTI-RESISTANT HOUSEFLIES}

\section{By H. WICHMAND}

Government Pest Infestation Laboratory, Springiorbi, Denmark

$\Delta \mathrm{S}$ the fly-populations on practically all Danish farms (owing to an excellent organization of the control) have developed resistance to the chlorinated hydrocarbons used as insecticides, in $1951 \mathrm{I}$ examined the possibilities of safely using Parathion in fly control. Obviously it would be too dangerous to spray this substance on the walls of stables, pigsties, etc., and furthermore, the Parathion would be rapidly hydrolysed by the lime-wash with which all the stable walls in Denmark are covered.

So we looked for a cheap but still sufficiently strong material which might be impregnated with Parathion and used as strips suspended under the ceilings like festoons. In the United States, strips of metal screen treated with Dieldrin and other chlorinated hydrocarbons have been used for fly-control ${ }^{1}$, but this material was too expensive for us, and we found gauze strips (as used for bandages) most suitable for the purpose. Laboratory investigations showed that gauze impregnated with a $2 \cdot 5$ per cent solution of 35 per cent Parathion had a rapid killing effect on houseflies, and that the gauze strips after suspension for two months in an air-conditioned room with a constant temperature of $25^{\circ} \mathrm{C}$. and continuous air renewal still had the effect that, of flies transferred to cages covered by the strips, 96 per cent were paralysed within two hours, and 100 per cent within three hours. Then experiments were carried out in two stables seriously infested with flies. Approximately $1 \mathrm{~m}$. of gauze was used for every square metre of ceiling, and after a fow days the fly population had been reduced from a number of about two hundred per animal (cows, horses and pigs) to two or three per ten animals.

A report was published eventually in a Danish farmers' bulletin, and the pesticide industry began 